8 年以上経過し, 胸壁, 胸腰椎, 肝臓に転移した, 上行結腸間膜より発生した粘液性囊胞腺腫の 1 例

宮崎県立延岡病院外科

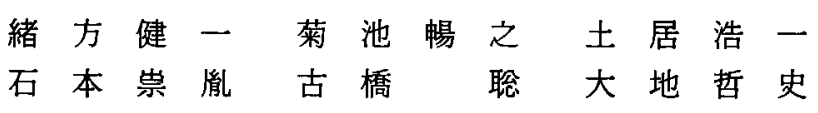

結腸間膜より発生したと思われる粘液性襄胞腺腫で，長期にわたり経過し，多発性骨 転移をおこし，急速に進行した症例を経験したので報告する．症例は62歳の女性で，8 年前より右側腹部腫瘍を自覚していたが放置. 平成 14 年 8 月下旬頃より腰痛出現し,

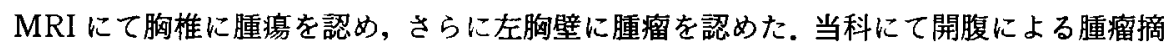
除術,および胸壁の腫瘤摘除術を施行した。切除標本にて境界悪性型の粘液性変胞腺腫 と診断された。術後, 胸腰椎転移が增大進展し, 肝転移も認めた。疼痛コントロール不 良となり，モルヒネを増量するも全身状態悪化し，永眠された。本邦では，腸間膜発生 の粘液性哓胞腺腫は 1 例のみしか報告例がなく，海外でも数例しかない．

索引用語：粘液性襄胞腺腫, 上行結腸間膜腫㿟, 多発性転移

\section{緒言}

粘萑性咅胞腺腫は，腹腔内で発生するものは卵巣原 発のものが多く,ついで, 膵臓, 虫垂, 稀に後腹膜に みられる. 腸間膜原発の粘液性基胞腺腫は極めて稀な 疾患で，悪性度も低く，良性であることが多い.今回， 上行結腸間膜より発生したと思われる粘液性葓胞腺腫 で，長期経過中に多様な転移を示した症例を経験した ので, 若干の文献的考察を加え報告する.

\section{症例}

患者：62歳，女性.

主訴: 腰背部痛.

既往歴：特記事項なし。

家族歴：特記事項なし。

現病歴：8 年以上前より右側腹部腫瘍を自覚してい たが放置した。平成14年 8 月26日頃より腰背部痛出現 した。急性腰痛症, 変形性腰痛症の診断にて近医で入 院加療を行っていたか，痛み持続した. MRI を施行し たところ多発性腰椎腫場を指摘され，9月19日当院整 形外科を受診し入院となったが, 腹部腫瘤を指摘され, 9 月24日当科入転科となった。

2006年 1月16日受付 2006 年 3 月 1 日採用

〈所属施設住所〉

=882-0835 延岡市新小路 $2-1-10$
入院時現症：身長 $152 \mathrm{~cm}$, 体重 $60 \mathrm{~kg}$ と BMI 25.9 と 過体重. 右側腹部に小児頭大の腫瘤を触知，また，右 胸壁にも $10 \mathrm{~cm}$ 大の腫瘤を認めた。

入院時検查所見 : 末梢血 $\mathrm{Hb} 10.7 \mathrm{~g} / \mathrm{dl}$ と軽度實血, 血液生化学検査で GOT 82IU/L, GPT 143IU/L, LDH 402IU/L, ALP 842IU/L, ALP 842IU/L, $\gamma$-GTP 247 $\mathrm{IU} / \mathrm{L}$ と肝機能異常と胆道系醉素の上昇がみられた。 腫場マーカーは CEA $17.0 \mathrm{ng} / \mathrm{ml}$ (正常值6.7以下), CA19-9 2365.6U/ml (正常値37以下) と上昇がみられ た.

胸腹部 CT 検査：右側腹部に内部は比較的均一な多 房性の襄胞性腫瘤を認め, 襄胞隔壁に一部石灰化を認 めた(図 $1 \mathrm{a}$ )。また，左胸壁に内部に石灰化を伴う充 実性腫瘤を認めた（図 1 b)，

腹部 MRI 検查 (図 $1 \mathrm{c}, \mathrm{d}$ ) : 右腹部の腫場は右腎 下極外側と一部接しており，腫瘍尾側背側は後腹膜に 接していた，腫瘍はCT の所見と同様，多房性て隔壁 の一部には壁在結節が認められ，一部隔壁が軽度 enhance されていた。

注腸 X 線写真検査：上行結腸が内側に圧排されて いた.

血管造影検查：右側腹部に無血管領域が認められ, 同部位での右結腸動脈，回結腸動脈の圧排が認められ た. 腫瘍への栄養動脈や腫湯濃染像は認められなかっ 

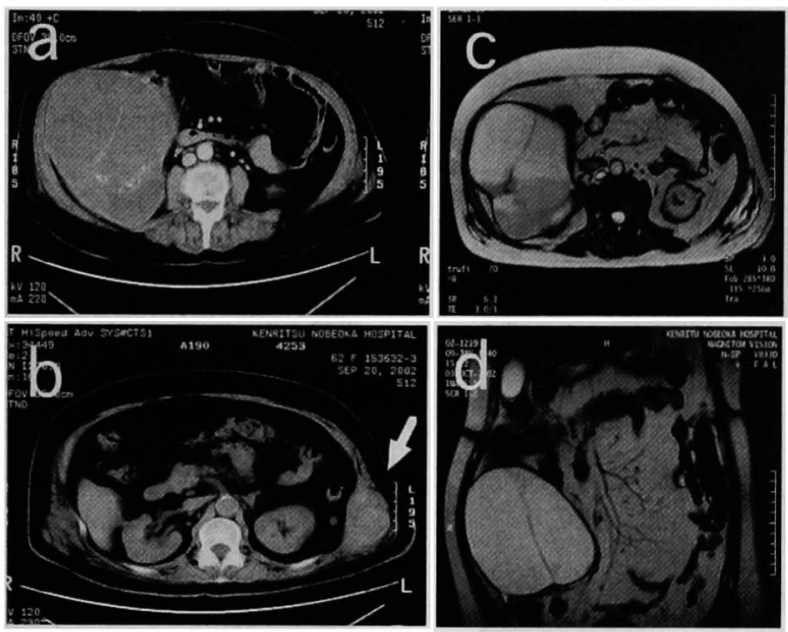

図 1 a， b CT 検査：a）右側腹部に多房性の蕉胞性腫瘤あ り. 壁に一部石灰化を認める， b ) 左側胸部に内部に石灰化を 伴う充実性の腫瘤あり (矢印).

c, d MRI 検査: CT の所見と同様, 多房性の襄胞性腫 瘤あり。

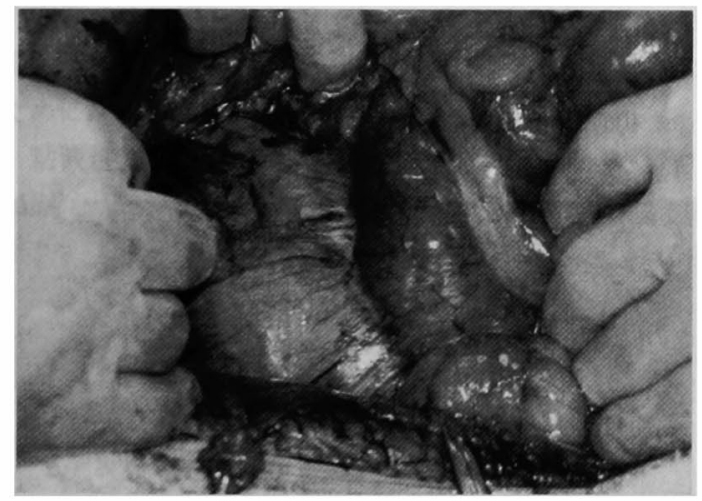

図 2 開腹所見：上行結腸外側に表面平滑な腫晹を認め た.

た.

骨シンチ検査 : 左第11肋骨背外側部，右足関節部， Th8〜10，12などに集積が認められた。

臨床経過：以上の所見より,腸間膜もしくは後腹膜 原発の襄胞性腫瘍が疑われた。10月21日開腹による腹 部腫瘤摘除術, ならびに胸壁腫瘤摘除術を施行した。

手術所見：上中腹部正中切開にて開腹した. 上行結 腸外側に表面平滑な $15 \mathrm{~cm}$ 大の腫㰾あり（図 2 ）。腫場 外側で壁側腹膜を開け，上行結腸間膜ならびに壁側腹 膜と腫場との間を大腸を損傷しないように剥離してい

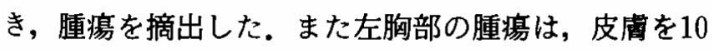

$\mathrm{cm}$ ほど横切開し, 皮下を剝離し,筋層内に埋もれた腫 瘍を剥離し腫演を摘除した。

摘出標本肉眼所見 : 腹部腫瘤の大きさは $15.0 \times$ $16.0 \times 13.5 \mathrm{~cm}$, 重さ $1,400 \mathrm{~g}$ (図 $3 \mathrm{a}$ ), 充実部はなく, 糞胞被膜に一部石灰化を認め, 内溶液は泥状の液体で あった(図 3 b，c）．また, 胸壁腫溜の大きさは，9.7× $5.5 \times 4.0 \mathrm{~cm}$, 重さ $130 \mathrm{~g}$ で充実性, 割面にて内部に石灰 化を伴っていた.

病理組織学的所見：襄胞性腸間膜腫瘍はゴブレット 細胞を伴う intestinal typeの腫場上皮に覆われてい た. 中等度の核異型はあるも, 腫場性上皮の多層化, 篩状増殖, 明らかな間質浸潤, 分裂像はみられず, 粘 液性壤胞腺癌の診断は否定され, 境界悪性型の粘液性 襄胞腺腫の診断であった(図 4 a). CEA 染色では, 腫 湟上皮が茶色に染まっており，CEA 陽性であった(図 4 b). その他の免疫染色では, ER, PgR はともに陰 性, cytokeratin (CK)7と CK20は一部陽性であった。 病理学的には発生の母地は不明であるが手術所見から 腸間膜に発生したものと診断した。胸壁腫瘍は, 核異 型が強く, 間質内への漫潤がみられ，原発巣より悪性 度が高くなっていた。 中分化型腺癌の診断であった。

術後経過：平成14年11月14日より12月 2 日まで, 多 発性骨転移（Th8-12，L1) に対する疼痛除去の目的に て, 放射線照射施行開始した. 計 8 回, Total $30 \mathrm{~Gy}$ 行 つた，放射線照射による除痛効果はほとんど認めず， 


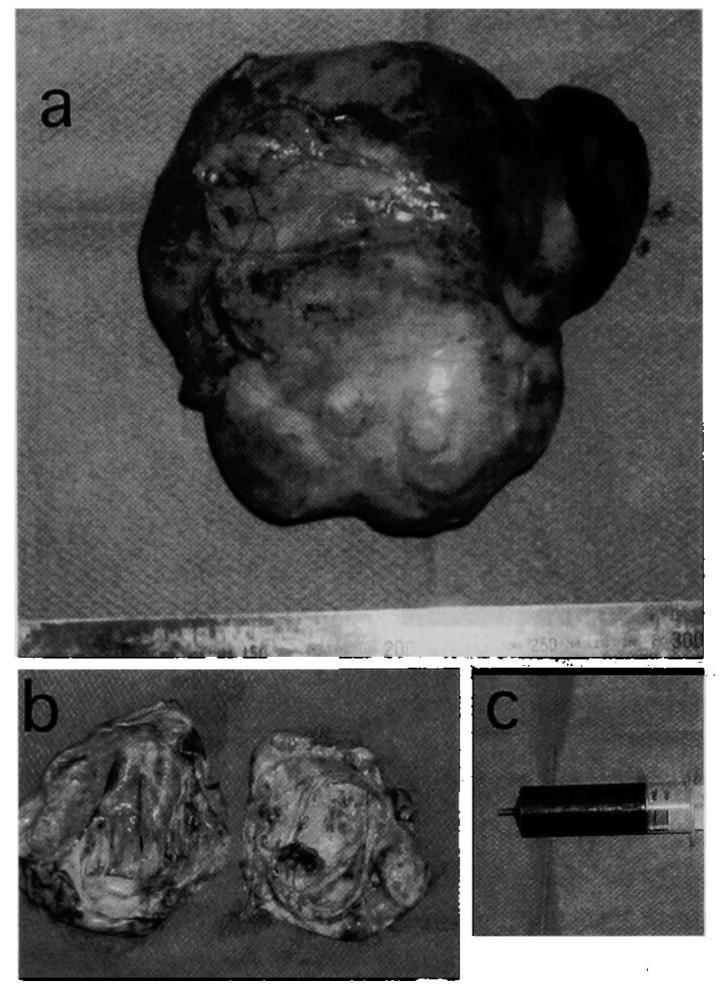

図 3 腹腔内腫瘤切除標本：a ） $15 \times 16 \times 13.5 \mathrm{~cm}$ の多房 性腫㿇であった。 b ) 内部は多房性の構造を呈してい た. c）内部には泥状の液体か眝留していた。

むしろ, 疼痛は増加していった．また，次第に術後よ り塩酸モルヒネを開始し, 次第に増量. 平成15年 1 月 15日の時点で40mg/時程の量でコントロールした. 12 月25日の MRI では多発性骨転移は急速に進行, L2, 3 椎体左側には 4 〜 $\mathrm{cm}$ の不規則な腫瘤を形成してい た(図 $5 \mathbf{a} ， \mathbf{b}$ )。また，12月27日の腹部 CTでは S6領 域に2.5cm の転移性腫瘍を認めた。さらに胸腰椎転移 が増大し, 全身状態要化. 平成15年 2 月 4 日, 永眠さ れた。

\section{考 察}

粘液性唭胞腺腫は, 腹腔内で発生するものは卵巣原 発のものが多く，ついで，脺蔵，虫垂にみられる．腸 間膜ならびに後腹膜原発の粘液性亯胞腺腫, 虽胞腺癌 は稀であり，これらを原発であると断言するには，卵 单, 虫垂, 膵臓などの他臓器に原発となるような腫湯 を認めず,なおかつこれら蔵器と境界が明瞭であるこ とが必須である，本症例の場合も，他臟器と離れてお り, 後腹膜とも境界が明瞙であることにより, 上行結 腸間膜原発と診断した。
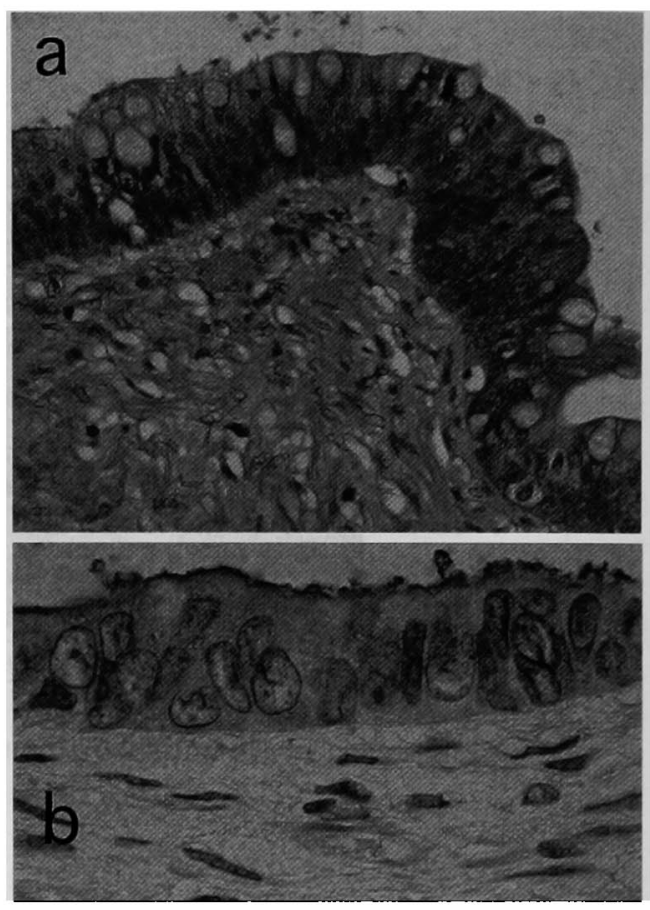

図4 組織所見：a）HE 染色 $(\times 200)$ : 細胞異型は 少なく,境界悪性の診断であった. b) CEA 染色( $\mathrm{X}$ 400）にて陽性の診断であった。
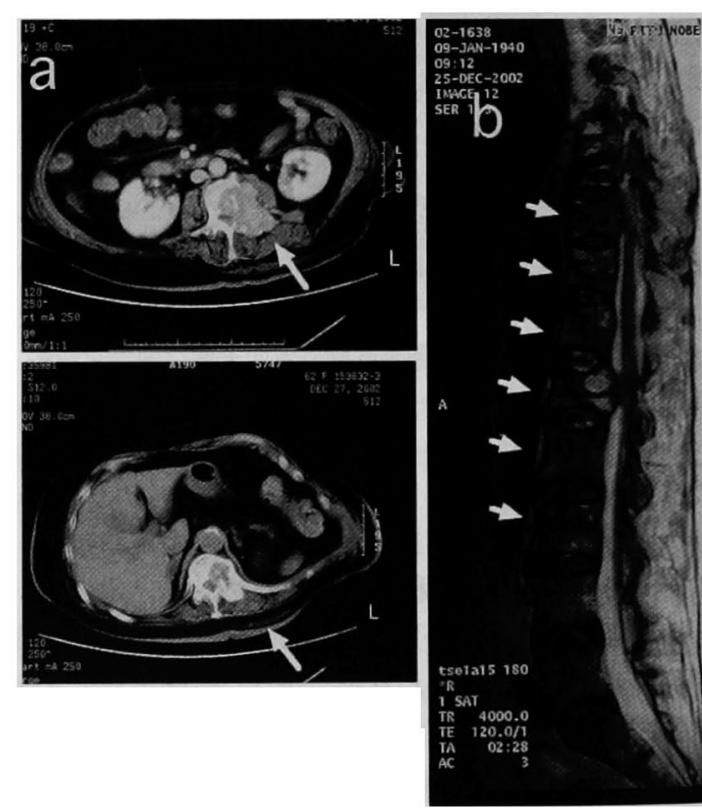

図 $5 \mathrm{a}$ CT 検查：胸腰椎に破骨性の腫㿔を認める(矢 印).

b MRI 検査：同榚に多発性に胸腰椎の腫瘤を認 めた（矢印）。 
後腹膜や腸間膜に発生する粘液性豪胞腺腫ちよび保 胞腺癌は, 腫瘍の組織構成が本来の後腹膜や腸間膜に 存在しない粘液産生上皮の増殖からなるため, その発 生母地や組織発生に興味がもたれている.Rothら”は 後腹膜に発生した粘液性蘘胞腺癌に卵巣間質類似組織 を認めたことから，異所性卵巣組織を発生母地の一つ として示唆しているが, Pannell ら²)にり卵巣以外に 奇形腫や中皮（体腔上皮）の迷入による化生上り発生 する，などの説もあげられている．本症例は病理組織 学的に奇形腫や卵巣組織を認めず $\mathrm{ER}, \mathrm{PgR}$ の免疫染 色は陰性であったが，CK7や CK20が一部陽性である ことより異所性卵巣組織の可能性は否定できないもの と思われた。

粘液性衰胞腺腫の原発巣は悪性度の低いものが多い が，長期にわたると転移を起こす可能性があるが，非 常に稀である，木村らの報告3)では腸間膜原発の粘液 性美胞腺腫の報告は，本邦では木村らの報告例のみて あり，海外でも 9 例の報告4ー9)を諗めるのみであると 報告している。本症例で本邦 2 例目であるが，木村ら の症例ては転移を示していなかった。本症例でも，組 織は境界悪性であったが，長期間にわたって経過した ために，転移を示したと思われる。

粘液性亯胞腺腫の診断は腹部超音波検查や CT, MRI などが有用であるが, 内容成分あるいは良悪性の 鑑別までは困難なことが多い，一般的に毫胞壁の不整 や周囲組織への漫潤, 周囲リンパ節の腫大などのほか, 億腫の一部に石灰化や充実性部分を認める場合は悪性

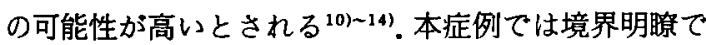
あるが，術前の造影 CT および MRIにて壁とともに 淡く漞染される充実成分を疑われ，また，一部石灰化 を伴っていたため，悪性が疑われた。ささらに，術前の 腫瘍マーカーにおいて CEA, CA19-9が高値であった ことも，悪性を示唆する所見であり，免疫組織像でも CEA 陽性を確認した. 組織学的には境界悪性の診断て あったが，臨床的には悪性であると考えられた．血清 CEA 值が正常であっても穿刺にて採取された赛胞内 容液中 CEA の高值であれば悪性の診断に役立つこと が報告されている13).

治療方針は，本症例のように長期にわたり放置して いると全身転移をおこす可能性があることから，やは り発見後早期に外科的切除することが望ましいと考え られる.最近は腹腔鏡下手術の報告 ${ }^{15)}$ もるが,腹膜播 種やポート部再発などの危険性が指摘されている 悪性の可能性がある場合, 裹胞壁を破罗せず, 内容物
を腹腔内に漏出することのないよう，外科的に完全摘 出することが第 1 選択となる.

$$
\text { 結 語 }
$$

上行結腸間膜原発と考えられる粘液性喜胞腺腫の 1 例を経験した．本症例は，腸間膜原発の粘液性衰胞腺 腫としては本邦で2 例目であり，転移を示した症例て は本邦初である。一般的に, 粘液性辜胞腺腫は悪性度 は低いが，長期にわたって放置すると，遠隔転移を起 こし，予後不良となることが示唆され，発見早期に外 科的に完全切除することが望ましいことが示唆され た。

本論文の要旨は第58回日本消化器外科学会総会 $(2003$ 年 7 月, 東京都）において発表した.

$$
\text { 文献 }
$$

1) Roth LM, Rhrlich CE : Mucinous cystadenocarcinoma of the retroperitoneum. Obst Gynecol 49 : 486-488, 1977

2) Pannell TC, Gusdon JP: Retroperitoneal mucinous cystadenoma. Am J Obstet Gynecol $160: 1229-1231,1989$

3）木村憲央, 村田暁彦，小山 基他：腸間膜から発 生した粘液性董胞腺腫の1 例. 日臨外会誌 66 ： 2296-2300, 2005

4) Banerjee R, Gough J : Cystic mucinous tumours of the mesentery and retroperitomeum : report of three cases. Histopathology $12: 527-532$, 1988

5) Cohen I, Altaras $M$, Lew $S$, et al: Huge mesenteric mucinous cystadenoma in normal pregnancy. Obstet Gynecol $71: 1030-1032$, 1988

6) McEvoy AW, Cahill CJ, Jameson C: Mucinous cystadenoma of the sigmoid mesocolon : a previously unreported abdominal tumor. Eur $\mathrm{J}$ Surg Oncol 23 : 88-90, 1997

7) Felemban $A$, Tulandi $T$ : Laparoscopic excision of a mesenteric cyst diagnosed preoperatively as an ovarian cyst. J Am Assoc Gynecol Laparosc $7: 429-431,2000$

8) Talwar A, Bell NJ, Nicholas D: Mucinous cystadenoma of colonic mesentery : report of a case. Dis Colon Rec 47 : 1412-1414, 2004

9) Kondi-Pafiti A, Papadias K, Kairi-Vassilatou E, et al: Extraovarian mullerian-type cystic 
tumors of the female. A report of six cases and review of the literature. Eur $j$ Gynecol Oncol $25: 657-659,2004$

10）大山司，宗田滋夫，橋本純平他：後腹膜に発生 した粘液性悉胞腺腫の 1 例。日臨外会誌 57 ： 2283-2287, 1996

11）高山仁志，伊藤寒一郎，東田 章他：馬踥鉄腎を 合併した後腹膜発生 Mucinous cystadenocarcinoma $の 1$ 例。泌紀 42：573-576，1996

12）上田通雅, 池田光之, 西江 浩他：後腹膜原発粘 液性塞胞腺癌の 1 例。日臨外会誌 $56 ： 1722-$ 1726, 1995

13）松野直徒，辻 孝彦，内山正美他：後腹膜原発の
粘液性葽胞腺癌の 1 例. 日臨外会誌 $62: 542-$ 545,2001

14）才川義朗，片井 均，丸尾敬敏他：後腹膜原発の 粘液性衰胞腺癌の 1 例. 日消外会誌 $25: 916-$ 920, 1992

15) Felemban A, Tulandi $T$ : Laparoscopic excision of a mesenteric cyst diagnosed preoperatively as an ovarian cyst. J Am Assoc Gybecol Laparosc $7: 429-431,2000$

16) Jin SC, Wei JL, Yun JC, et al: Laparoscopic resection of a primary retroperioneal mucinous cystadenoma : Report of a case. Surg Today $28: 343-345,1998$

\title{
A CASE OF MUCINOUS CYSTADENOMA ORIGINATING FROM MESOCOLON WITH METASTASIS OF BONE, CHEST WALL AND LIVER
}

\author{
Kenichi OGATA, Nobuyuki KIKUCHI, Koichi DOI, Takatsugu ISHIMOTO, \\ Satoshi FURUHASHI and Tetsufumi OHCHI \\ Department of Surgery, Miyazaki Prefectual Nobeoka Hospital
}

\begin{abstract}
A 62-year-old woman had been aware of a tumor in her right abdomen over eight years, but had left it alone. She complained of backaches at the end of August, 2002. Computed tomography (CT) and MRI showed an abdominal cystic mass about $15 \mathrm{~cm}$ in diameter, a tumor of around $6 \mathrm{~cm}$ in diameter in the left chest wall, and multiple spinal metastasis. We performed an abdominal cystic mass extirpation and chest wall mass extirpation. After this operation, chest lumbar spine metastasis increased and progressed, and hepatic metastasis appeared. Pain control became difficult, and though we increased the amount of morphine, but her general condition worsened, and she died. Generally, many cases of mucinous cystadenoma are reported to be benign or borderline malignancies. We report a very rare case of mucinous cystadenoma that was considered to have occurred from mesocolon, progressed rapidly, and caused manifold metastases.
\end{abstract}

